\title{
RESUME HUKUM TATA NEGARA
}

NAMA : AYU WARDANI

NIM : 10200120204

KELAS : HUKUM TATA NEGARA

\section{ISTILAH HUKUM TATANEGARA}

Hukum tata negara adalah peraturan-peraturan yang menentukan badan badan yang diperlukan peserta kewenangan masing-masing hubungannya satu sama lain.hukum tatanegara juga mengatur semua masyarakat hukum atasan dan masyarakat hukum bawahan menurut tingkatannya,hukum tata negara adalah hukum yang mengatur dan mengenai organisasi negara.

a).ruang lingkup kajian

ruang lingkup kajian hukum tatanegara adalah mengenai organisasi negara yang mencakup mengenai lembaga-lembaga negara,ubungan satu dengan yang lain,dengan kekuasaaanya.selain itu,juga mencakup mengenai warga negara termasuk hak asasi manusia (HAM),dan wilayah negara.

b).hubungan dengan ilmu lainnya

ilmu negara memberikan dasar-dasar teroritis kepada HTN positif,sedangkan HTN merupakan kongkretisasi dari teori-teori ilmu negara.hal ini merupakan bekal untuk dapat berkecimpung langsung dengan hukum positif yang merupakan salah satu objek HTN.

c).hubungan antara hukum administrasi negara dengan hukum tatanegara

hukum administrasi negara tak lepas dari definisi administrasi administrasiadministrasi:segenap rangkaian kegitan penataan terhadap pekerjaan pokok yang dilakukan sekelompok orang dalam kerjasama mencapai tujuan tertentu (etika administrasi pemerintahan,the liang gie,djohermansyah djohan,milwan),kemudian administrasi dalam arti sempit yang berbunyi semua kegiatan tulis menulis,ketik mengetik,catat mencatat,surat menyurat serta pengurusan yang berkaitan dengan ketatausahaan.

d).hubungan HTN dengan ilmu politik

hukum tatanegara mempelajari peraturan-peraturan hukum yang mengatur organisasi kekuasaan negara sedangkan ilmu politik mempelajari kekuasaan dilihat dari aspek perilaku kekuasaan tersebut.

\section{SUMBER-SUMBER HUKUM TATA NEGARA}

a).pengertian sumber hukum

sumber hukum ialah segala sesuatu yang telah menimbulkan aturan-aturan yang telah menimbulkan aturan-aturan yang mempunyai kekuatan yang bersidat memaksa,artinya 
yaitu aturan-aturan yang kalau dilanggar akan mengakibatkan sanksi yang tegas dan nyata.sumber hukum dapat dibedakan kedalam 2 (dua) bagian yaitu:

- Sumber hukum dalam arti materiil;dan

- Sumber hukum dalam formal

$>$ Sumber hukum materil adalah tempat dari mana materi itu diambil,sumber hukum materil ini merupakan faktor yang membantu pembentukan hukum,misalna hubungan sosial,hubungan kekuatan politik,situasi sosial ekonomis,tradisi (pandangan keagamaan dan kesusilaan),hasil dari penelitian ilmiah (kriminologi dan lalulintas),perkembangan internasional,serta keadaan geografis.ini semua merupakan objek studi penting bagi sosiologoi hukum.

$>$ Sumber hukum forml merupakan tempat atau sumber dari mana suatu peraturan memeroleh kekuatan hukum,hal ini berkaitan dengan bentuk atau cara menyebabkan peraturan hukum perjanjian antar negara,yurisprudensi,dan kebiasaan.

Menurut E.Utretch,sumber-sumber hukum formal yaitu:

- Undang-undang

- Kebiasaan dan adat

- Traktat

- Yurisprudensi

- Pendapat pakar hukum yang terkenal (donkrit)

Salah satu yang dapat dikategorikan sebagai sumber hukum yang tidak tertulis adalah konveksi ketatanegaraan(kebiasaan,kezaliman dst).contoh penerapannya adalah pidato kenegaraan president disetiap tanggal 16 agustus dihadapan perlemen.pidato kenegaraan tersebut tidak diatur dalam peraturan perundang-undangan,tetapi secara berkelanjutan dilakukan oleh semua presiden.contoh lainnya adalah penerapan hukum adat.

Sedangkan untuk konveksi pidato tgl 16 agustus itu masuk kategori konveksi ketatanegaraan,tidak ada dasar hukumanya secara tetulis,tetapi karena sudah menjadi tradisi ketatanegaraan,maka kegiatan tersebut tetap dilaksanakan,jadi konveksi ketatanegaraan maka kegiatan tersebut tetap dilaksanakan,jadi konveksi ketatanegaraan itu,tidak diatur secara tertulis dalam peratura undang-undangan.

Mulai undang-undang dasar peraturan perundang-undangan,yurisprudensi,traktat,konveksi dan dokrin.

\section{ASAS-ASAS HUKUM TATA NEGARA}

Menurut pasal 1 ayat 2 UUD RI 1945 "kedaulatan berada di tangan rakyat dan dilaksanakan menurut UUD”yang artinya konsep kekuasaan tertinggi bernegara adalah kehendak rakyat kekuasaan tertinggi bernegara adalah kehendak rakyat dengan mekanism konstitusi.nah,apakah sistematika dai konsep pasal 1 ayat 2 telah diterapkan dengan semestinya,karena sudah menjadi perintah konstitusi,penilaian terhadap penerapan pasal a quo tertentu akan berbeda-beda dan sangat tergantung dari aspek mana,misalnya dari aspek perundang-undangan,khususnya dalam pembentukan UU cipta kerja,yang dimana tidak mencermikan penerapan pasal tersebut,karena pemerintah dan DPR mengabaikan gelombang protes sebagai wujud ketidak setujuaan terhadap RUU tersebut.padahal pembentukan UU 
harus sesuai dengan keinginan masyarakat,tetapi dari aspek lain,mungkin orang akan berpandangan bahwa pasal aquo telah diimplementasikan.

1).peran dan fungsi asas

Sebagai titik tolak dari hukum positif yang dapat berwujud undang-undang dan putusan hakim.satu hal yang menjadi kendala dalam menyamatkan pendapat adalah karena latar belakang para ahli yang berbeda-beda.ahli yang berlatar berlakang sosiologi hukum akan merumuskan pengertian asas hukum sesuai dengan kompetensinya,begitupun dengan pakar yang berlatar belakang sejarah dll.karna kalau masyarakat yang tidak mengerti akan asas hukum pasti mengalami kebingungan karna berbagai macam pendapat yang melatar belakangi hal itu,sehingga jika kita menilai aspek-aspek tertentu,akan sangat,memungkinkan kita menemukan kondisi dimana akan disimpulkan bahwa pasal aquo belum terimplementasi,misalnya penerapan pasal 33 dan pasal-pasal lain di dalam undang-undang dasar.belum lagi pandangan dari orang-orang/pihak-pihak secara langsung merasa dirugikan secara konsitituasional oleh kebijakan pemerintah.

2).sifat asas-asas hukum

Hukum positif wajib merujuk pada asas-asas hukum yang berlaku,[embentukan hukm positif (peraturan perundang-undangan) yang bertentangan dengan asas harus di cabut,apalagi jika misalnya bertentnagan dengan asas pancasila atau asas negara hukm,dst.

Oleh karena itu sifat dari asas hukum itu tidak konkrit,maka asas hukm tidak secara langsung mengatur mengenai sanks,tetapi pengaturan sanksi bagi penyelengaraan negara yang tidak taat asas diatur dalam norma hukum.

Dalam asas pemisahan kekuasaan pemerintah masing-masing daerah memegang kendali atas daerahnya sendiri,penyelengaraan negara betul betul menyadari lalu kemudian menerapkan niain-nilai pancasila,maka sangat kecil peluang terjadinya penyimpagan dalam proses penyelengaraan negara prsktik-pratik koruptif tidak akan terjadi jika nilai-nilai pancasila dapat diterapkan.

Kalau bicara tentnag sumber hukum,khususnya dinegara-negara eropa kontinental,maka hukum positif menjadi salah satu sumber hukum yang utama,tetapi jika dibandingkan antara asas hukum dan norma hukum,karna dalam pemebentukannya norma hukum wajib merujuk pada asas-asas hukm yang berlaku.

\section{3).kasus yang paling mendominasi}

Kita ketahui,kasus yang paling kasus yang paling mendominasi indonesia di indonesia adalah kasus korupsi yang dilakukan oleh para pemegang jabatan.korupsi sebagai extra ordinary crime tentu membutuhkan upaya upaya yang luar biasa dana keterbitan seluruh elemen termasuk masyaralat.pemberantasan korupsi tidak akan berhasil jika hanya dilakukan dengan cara yang biasa-biasa saja.

Apalagi saat ini,perilaku koruptif tidak hanya terjadi pada level pemerintahan pusat tetapi sudah sampai pada level pemerintah paling bawah.Political will pemerintah,kesungguhan aparat penegak hukumdan peran serta masyarakat harus seirama,karena ketiganya memiliki 
peran yang sangat vital.membenagun sistem yang kuat tanpa disertai dengan aparatur/enyelenggara yang berintegrsi tetap tidak akan berhasil.buktinya berbagi inovasi pelayana telah dilakukan,tetapi praktik suap/gratifikasi tetap terjadi karena sistem dijalankan oleh aparat/penyelenggara yang tidak berintegrasi.sikap pesimis masyarakat dan bhakan cenderung mengaggap hal biasa dalam memberikan uang capek dalam proses pemberian layanan publik pastinya akan semakin melestarikan perilaku kopriptipf.jika menggunaka teori sistem hukum dari fiendam,maka ketiganya haru bersinegri dan satu komando.

Masyarakat sebegai pemegang kedaulatan berhak untuk mengkoreksi setiap tindakan pemerintahaan yang dilakukan oleh penyelenggara negara.sarana-sarana konstitusional untuk menguji setiap kebijakan/tindakan pemerintah telah tersedia untuk hal itu,meskipun terkadang sarana tersebut tidak efektif.tetapi kita tidak boleh pesimis dan tetap harus berikhtiar untuk mengawal dan terus mengigatkan para wakil rakyat baik legislatif,eksekutif dan yudikatif untuk terus berbenani.

Seseorang dapat menerapkan meskipun tidak ada peraturan yang melarang perbuatan yang dilakukan orang tersebut,namun,kemungkinan tersebut bukan karna yurisprudensi.asas legalitas perjanjian dalam ranah hukum pidana dan terkenal dengan adagium legendaris von feurbach yang berbunyi nullum delictum nulla poena sine praevia lege poenali.secara bebas,adagium tersebut dapat diartikan menjadi "tidak ada tindak pidana (delik),tidak ada peraturan yang mendahulunya",secara umum pembagian kelompok adagium tersebut menjadi tiga bagian.yaitu:

1.tidak ada larangan,kalau tak ada undang-undang

2.tidak ada hukum,kalau tidak ada kejahatan

3.tidak ada kejahatan,kalau tidak ada undang,yang berdasarkan undang-undang.

Adagium tersebut merupakan dasar dari asas bahwa kententuan pidana tidak dapat diandalkan (asas non-retroaktig) karena suatu delik hanya dapat dikatakan sebgaia kejahatan telah ada atauran sebelumnya yang melarak delik untuk dilakukanbukan sesudah delik tersebut dilakukan.sistem hukum yang berlaku di indonesia tidak sama seperti sistem hukum anglosaxon yang menganut aliranfreie rechtslehre yang memperbolehkan hakim untuk menciptakan hukum.sistem hukum diindonesia menganut alitan alitan rechtsvinding yang perkiraan hukum harus berdasarkan putusannya kepada peraturan-undangan yang berlaku.hal ini selaras dengan ketentuan pasal 20 algemene bepaling van wetgeving voor indonesia ("AB") yang menyatakan bahwa hakim harus mengadili suatu perkara.

Pada beberapa kesempatan,hakim akan dihadapkan kepada keadaan harus mengadili suatu perkara yang tidak memiliki dasar hukum atau pengaturan hukumnya tidak jelas dalam keadaan ini,hakim tidak menolak untik mengadili perkara tersebut dengah dalih tidak ada hukum yang berbicara.

Hal ini sesuai dengan pasal 10 ayat (1) undang-undang no.48 tahun 2009 tentnag kekuasaan kehakiman ('UU 48/2009')yang berbunyi:

"pengadilan dilarang untuk memeriksa,mengadili,dan memutus suatu perkara yang diajukan dengan dalil bahwa untuk memeriksa dan mengadilinya."

Juga dengan pasal 5 ayat (1) UU 48/2009 yang berbunyi: 
"hakim dan hakim konstitusi wajib mengambiol,mengikuti dan memahami nilainilai hukum dan rasa keadilan yang hidup dalam masyarakat.:

Selain dua ketentuan tersebut,pasal 22 AB juga menyatakan bahwa hakim menolak untuk mengadili dengan alasan undang-undangnya bungkam,tidak jelas atau tidak lengkap,dapat dituntut karena menolak untuk mengadili.

Dengan demikian,dapat diambil kesimpulan bahwa hakim harus mendasarkan putusannya dalam mengadili kepada peraturan perundang-undangan dan bebas untuk menafsirkan dan menginterprestasikan hukum tersebut.meskipun demikian,dalam hal perkara yang diadili tidak ada atau tidak jelas dasar hukumnya,hakim pun tetap wajin mengadili perkara tersebut,sehingga prinsipnya,asas legalitas harus dijadikan kasus yang sedang mereka tangani.Dalam hal puusan tersebut berlangsung sekian lama dan diputus oleh pengadilan tertinggi (Mahkama Agung),maka pututsan tersebut dapat menjadi yurisprudensi.Yurisprudensi merupakan salah satu sumber hukum formal selain undangundang,kebiasaan dana traktat.

Pada prisipnya,asas legaliatas harus dijadikan pedoma awal bagi hakim untuk mengadili kasusu yang sedang mereka tangani kita ambil contoh diindonesia hakimnya itu tidak terikat untuk melaksanakan yurisprudensi karena mengapa,Yurisprudensi hanya dianggapp sebagai pedoman atau arahan memutus suatu perkara.oleh karena itu apabila terdapat pertentnagan antara hukum yang ada dengan yurisprudensi,yang berlaku ialah hukum.maka dari itu kebolehan hakim untuk menghukum seseorang tanpa adanya dasar hukum bukan karena yurisprudensi,melainkan kaena hal tersebut adalah prinsip dari keksuasaan kehakiman untuk menjadi keadilan.

Secara subtansi,potensi terjadinya pertentangan antara putusan hakim dapat menyimpangi peraturan perundang-undangan dengan dasar kemandirian dan keajiban hakimdalam menggali nilai-nilai yang hidup ditengah masyarakat.Apalagi hukum tertulis biasanya akan lambat mengikuti perkembangan zaman,sehingga hakim akan sulit untuk memberikan keadilam dalam putusannya.sementara tuntutan pencari keadilan tidak boleh diabaikan hanya karena aturannya yang sangat tidak relevan.

\section{Sejarah Ketatanegaraan Indonesia}

Dalam sejarah perjalanan ketatanegaraan Indonesia, sistem pemerintahan menjadi sesuatu yang selalu sangat menarik untuk dikaji. Hal ini disebabkan bukan saja karena dalam sejarah ketatanegaraan Indonesia pernah memberlakukan sistem pemerintahan Presidensil maupun parlementer, tetapi juga karena dalam pelaksanaan kedua sistem tersebut sering menimbulkan permasalahan karena ketidaktegasan dan ketidakjelasan terhadap sistem yang diberlakukan. Pada awal kemerdekaan, terlepas dari kondisi darurat dan sifat kesementaraannya. Undang-Undang Dasar yang ditetapkan Panita Persiapan Kemerdekaan Indonesia (PPKI) tanggal 18 Agustus 1945 mengatur dengan tegas bahwa sistem pemerintahan menganut sistem Presidensil. Hal ini dibuktikan dengan adanya ketentuan bahwa Presiden adalah sebagai Kepala Negara dan sekaligus sebagai Kepala Pemerintahan. Dalam menjalankan tugasnya ia dibantu oleh seorang Wakil Presiden. Dalam hal ini Presiden tidak bertanggung jawab kepada Dewan Perwakilan Rakyat, artinya kedudukan Presiden tidak tergantung kepada Dewan Perwakilan Rakyat. Di samping itu, Presiden juga dibantu oleh menteri-menteri. 
Menteri-menteri tersebut tidak bertanggung jawab kepada Dewan Perwakilan Rakyat, akan tetapi tergantung kepada Presiden. Menteri-menteri ini diangkat dan diberhentikan oleh Presiden.Undang-Undang Dasar 1945 memberikan wewenang tertentu kepada Presiden dalam menjalankan tugas pemerintahan. Namun demikian, pemberian wewenang tersebut tidak diikuti dengan batasan-batasan terhadap penggunaannya. Soekarno, sebagai Presiden pertama RI, dalam rapat pertama Panitia Persiapan Kemerdekaan Indonesia tanggal 18 Agustus 1945 menyatakan bahwa Undang-Undang Dasar 1945 adalah Undang-Undang Dasar kilat. Hal ini dikarenakan mendesaknya keinginan untuk memproklamasikan kemerdekaan pada saat itu sehingga infrastruktur bagi sebuah negara yang merdeka harus segera disiapkan. Oleh karena itu, hal tersebut menyebabkan Undang-Undang Dasar 1945 menjadi Undang-Undang Dasar yang singkat dan sangat multi interpretatif. Dalam melaksanakan kekuasaannya, Presiden diberikan kekuasaan yang sangat besar oleh Undang-Undang Dasar 1945, dimana pada masa awal pemerintahan, kekuasaan Presidendalam menjalankan pemerintahan bukan hanya sekedar berdasarkan Pasal 4, 5 10, 11, 12, 13, 14 dan 15 saja, tetapi juga berdasarkan Pasal IV aturan Peralihan yang berbunyi: "Sebelum MPR, DPR dan DPA dibentuk menurut Undang-Undang Dasar ini, segala kekuasaannya dijalankan oleh Presiden dengan bantuan sebuah Komite Nasional. Akibat dari ketentuan peralihan tersebut, Presiden dengan sah dapat bertindak sebagai diktator karena bantuan Komite Nasional sama sekali tidak dapat diartikan suatu pengekangan atas kekuasaannya.

Sistem Presidensil kembali berlaku ketika Presiden mengeluarkan Dekrit pada tanggal 5 Juli 1959, yang salah satunya isinya adalah kembali berlakunya UUD 1945 dan tidak berlakunya lagi UUDS 1950. Dalam pelaksanaan pemerintahan di masa yang disebut orde lama ini, Presiden benar-benar memiliki keleluasaan dan melakukan banyak tindakan yang nyata-nyata bertentangan dengan UUD 1945. Dengan alasan pelaksanaan demokrasi terpimpin, pemerintahan di bawah kepemimpinan Sukarno menjadi pemerintahan yang otoriter dengan kesewenang-wenangannya. Pelanggaran atas UUD 1945 dilakukan dengan terang-terangan, banyak produk hukum yang dikeluarkan secara sepihak oleh Bung Karno melalui Penetapan Presiden karena sang Presiden tidak mau mendengar suara DPR atau DPR-GR6. Kemudian dalam pelaksanaan masa orde baru, ternyata kekuasaan-kekuasaan lembaga eksekutif ini telah banyak pula menimbulkan berbagai masalah yang saat itu diwarnai pendapat pro dan kontra seputar penggunaannya. Hal tersebut dapat disebabkan karena tiga hal, yakni:Pertama, besarnya kekuasaan Presiden tersebut tidak diikuti dengan mekanisme dan pertanggung jawaban yang jelas. Padahal hak-hak tersebut sifatnya substansial bagi kehidupan bangsa sehingga memerlukan adanya kontrol, misalnya pemilihan duta dan konsul, penentuan susunan kabinet, wewenang untuk menyatakan perang, dan lain-lain. Kedua, fenomena ketidakpercayaan masyarakat terhadap pemerintah telah sedemikian besarnya sehingga menimbulkan sensitivitas dalam tubuh masyarakat terhadap tindakan-tindakan yang dilakukan oleh pemerintah, khususnya Presiden. Ketiga, berkaitan erat dengan yang kedua, sensitivitas ini juga didorong oleh tumbuhnya kesadaran masyarakat dengan sangat cepat dengan dipicu oleh atmosfir reformasi yang tengah berjalan pada saat ini. 


\section{a.Definisi Sistem Pemerintahan}

Istilah Sistem Pemerintahan berasal dari gabungan dua kata yaitu Sistem dan Pemerintahan. Sistem dalam Kamus Besar Bahasa Indonesia diartikan sebagai perangkat unsur yang secara teratur saling berkaitan sehingga membentuk suatu totalitas, susunan yang teratur dari pandangan teori, asas, dsb.7Menurut Moh. Kusnardi Sistem adalah suatu keseluruhan, terdiri dari beberapa bagian yang mempunyai hubungan fungsional baik antara bagian-bagian maupun hubungan fungsional terhadap keseluruhannya, sehingga hubungan itu menimbulkan ketergantungan antara bagian-bagian yang akibatnya jika salah satu bagian tidak bekerja dengan baik akan mempengaruhi keseluruhannya.8Sedangkan Pemerintahan adalah proses, cara, perbuatan memerintah; segala urusan yang dilakukan oleh Negara dalam menyelenggarakan kesejahteraan masyarakat dan kepentingan Negara. Pemerintahan dalam arti luas adalah pemerintah/lembaga Negara yang menjalankan segala tugas pemerintah baik sebagai lembaga eksekutif, legislatif dan yudikatif. Sedangkan menurut Donald A.Rumokoy istilah Pemerintahan dalam arti luas adalah segala urusan yang dilakukan oleh Negara dalam menyelenggarakan kesejahteraan rakyatnya dan kepentingan Negara sendiri, jadi di sini tidak hanya diartikan sebagai pemerintah yang hanya menjalankan tugas eksekutif saja akan tetapi juga meliputi tugas-tugas lainnya termasuk legislatif dan yudikatif.9Sistem Pemerintahan itu membicarakan bagaimana pembagian kekuasaan serta hubungan antara lembaga-lembaga Negara yang menjalankan kekuasaan-kekuasaan Negara itu dalam rangka menyelenggarakan kepentingan rakyat.1oOleh karena itu, Sistem Pemerintahan itu adalah aturan atau cara bagaimana ketiga lembaga tersebut bekerja dan berhubungan satu sama lain dimana setiap lembaga harus bekerja sama dan menjalankan tugasnya dengan baik sehingga tujuan untuk menyelenggarakan kesejahteraan masyarakat dan kepentingan Negara dapat terwujud.

\section{b.Pemberlakuan Kembali UUD 1945 pada Demokrasi Terpimpin}

Setelah pemberlakuan UUD 1945 kembali, rakyat menaruh harapan akan kehidupan ketatanegaraan yang stabil dan pemerintah Presidensial yang demokratis. Akan tetapi, dengan penerapan Demokrasi Terpimpin menyebabkan terjadinya penyimpangan terhadap Pancasila dan UUD. Adapun bentuk penyimpangannya adalah :

a . Penyimpangan ideologis, konsepsi Pancasila diganti dengan Nasakom

b. Pemusatan kekuasaan Presiden dengan wewenang yang melebihi ketentuan UUD 1945, yaitu membentuk produkhukum tanpa persetujuan dari DPR

c. Dalam MPRS NO III/MPRS/1963 mengangkat Ir. Soekarnosebagai Presiden seumur hidup.

d.Kedudukan MPRS dan DPRS dijadikan Menteri negara sebagai pembantu Presiden.

Dengan berlakunya kembali UUD tanggal 5 Juli 1959, Indonesia memasuki periode demokrasi terpimpin. UUD 1945 menggunakan Sistem Pemerintahan Presidensial. Presiden Soekarno menjadi Kepala Negara sekaligus sebagai Kepala Pemerintahan RI Sistem kepemimpinannya disebut orde lama. Inkonsistensi penerapan Sistem Pemerintahan ini merupakan bentuk penyimpangan terhadap ketentuan UUD 1945 sendiri yang jelas-jelas mengatur Sistem 
Pemerintahan Presidensial. Namun keinkonsistensian penerapan Sistem Pemerintahan tersebut didasari atas konvensi ketatanegaraan dan hukum kebiasaan yang telah diterapkan sebelumnya. Disamping itu juga dapat dikatakan karena UUD 1945 sendiri memang dimaksudkan hanya sebagai revolutie -grondwet atau undang-undang dasar kilat (ucapan Bung Karno dalam sidang BPUPKI) yaitu undang-undang dasar yang hanya dimaksudkan sebagai naskah konstitusi untuk sementara waktu dalam rangka persiapan Indonesia menjadi Negara yang merdeka dan berdaulat.

Oleh karena itu, dapat dimaklumi bahwa UUD 1945 itu sendiri sejak masa awal kemerdekaan RI belum dijadikan referensi akan tetapi hanya sebagai sebuah syarat persiapan kemerdekaan Indonesia.

\section{c.Sistem Pemerintahan pada Orde Baru}

Selama rezim Orde Baru tidak terjadi perubahan Sistem Pemerintahan. Akan tetapi, pelaksanaan lembaga kePresidenan sangat dominan. Hal ini dapat dilihat di dalam UUD 1945 yang menyatakan tugas dan kewenangan Presiden mencakup tidak hanya bidang eksekutif, tetapi juga dalam bidang legislatif dan yudikatif. Selain itu, kelembagaan negara dan organisasi sosial politik cenderung berjalan kurang seimbang dan proposional. Pelaksanaan UUD 195 sebagai referensi Sistem ketatanegaraan baru dipraktikkan secara nyata pada masa orde baru. Jargon yang sering dipakai pada Pemerintahan ini adalah pelaksanaan UUD 1945 secara murni dan konsekuen. Orde Baru telah berhasil menyelenggarakan Pemerintahan melalui mekanisme kenegaraan yang dikenal dengan Mekanisme Kepemimpianan Nasional 5 tahun.

Mekanisme Kepemimpinan Nasional 5 tahun tersebut adalah :

1. Diadakannya pemilu untuk mengisi keanggotaan MPR, DPR, DPRD I, DPRD II.

2. MPR bersidang untuk memilih Presiden dan wakil Presiden serba menetapkan GBHN untuk 5 tahun.

3. Presiden membentuk kabinet yang bertanggungjawab terhadap Presiden. Kabinet melaksanakan tugas dibawah petunjuk Presiden dengan berlandaskan UUD dan GBHN.

4. Presiden bertanggung jawab kepada MPR. Presiden menyampaikan laporan pertanggungjawaban setiap akhir kepemimpinan kepada MPR.

5. DPR mengawasi jalannya Pemerintahan. DPR bersama Presiden membentuk UU.

Pada masa orde baru, tanggung jawab kekuasaan Negara terpusat di tangan Presiden (menganut Sistem Presidensial). Kedudukan Presiden sangat kuat sehingga meskipun MPR sebagai lembaga tertinggi Negara (tempat Presiden diharuskan tunduk dan bertanggung jawab) tetapi dalam kenyataannya kedudukan MPR tergantung pada Presiden. Adanya unsur pertanggungjawaban presdien kepada MPR justru memperlihatkan ciri Parlementer. Oleh 
karena itulah, secara normatif Sistem yang dianut oleh UUD 1945 bukanlah murni Sistem Presidensial akan tetapi hanya quasi Presidensial. Sifat quasi atau Sistem Presidensial tidak murni itulah yang diubah ketika UUD 1945 diubah pada tahun1999 sampai tahun 2002, yaitu dengan mengubah kedudukan MPR tidak lagi sebagai lembaga tertinggi Negara, melainkan lembaga Negara yang sederajat dengan Presiden. Disamping itu, perubahan UUD 1945 itu juga mengatur tentang pemilihan Presiden dan wakil Presiden oleh rakyat melalui pemilihan umum setiap lima tahun sekali.

\section{KONSTITUSI SEBAGAI OBJEK KAJIAN HUKUM TATA NEGARA}

Adapun tujuan dari kontitusi yaitu bertujuan untuk membatasi tindakan sewenang wenang pemerintah,Adapun contoh beberapa tindakan sewenang-wenang yang bertentangan dengan hak warga negara adalah.

a. Hakim meberi putusan suatu perkara berdasarkan bukti-bukti

b. Siswa dikeluarkan dari sekolah tindak kriminal

c. Polisi memberi tilang kepada siswa yang melanggar peraturan

d. Pemerintah daerah melarang penggunaan jilbab dari sekolah

e. Pemerintah memberikan hak pilih pada setiap warga negara.

Constitutional convetion biasanya terjadi terhadap suatu pasal yang secara yuridis masih berlaku,tetapi sudah tidak di terapkan,dan digantikan dengan praktik/kebiasaan ketatanegaraan.

Konvensi yang ada diindonesia mempunyai kedudukan yang penting,hal ini dapat dilihat setelah diproklamirkan pada tanggal 17 agustus 1845, indonesia merupakan negara yang merdeka.sehari setelah kemerdekaan tersebut,tepatnya pada tanggal 18 agustus 1945 disahkan pula undang-undang dasar 1945 sebagai konstitusi tertulis negara republik indonesia.berlakunya UUD 1945 sebagai konstitusi di indonesia terbagi menjadi dua tahap yaitu tahap pertama 18 agustus 1945 sampai dengan tanggal 27 desember 1945 sampai dengan tanggal 27 desember 1949,kemudian tahap kedua sejak denkrit president tanggal 5 juli 1959 sampai sekarang.

Fungsi dari konstitusi adalah mengatakan bahwa fungsi dari konstitusi adalah membatasi kesewenang wenangan pemerintah.jadi pemberantasan korupsi juga harus sesuai dengan konstitusi karena kalau tidak maka akan mengacu sistem ketatanegaraan.mengigatkan para pihak yang dituduh korupsi untuk bisa memperjuangkan hak mereka sesuai konstitusi.dalam hukum ketatanegaraan,seseorang hanya bisa dijerat dengan kasus korupsi hanya jika korupsi yang dimaksud sesuai dengan constitusional intent atau makna konstitusi.

Konstitusi dalam sebuah negara secara umum disepakati sebagai aturan dasar yang mengikat dalam kehidupan bermasyarakat,berbangsa,dan bernegara.Aturan-aturan hukum tercakup di dalammnya,termasuk aturan yang bertujuan mencegah dan memberantas korupsi.meski tidak disebutkan secara eksplisit didalam konstitusi,kejahatan korupsi tergolong kejahatan luar biasa bagi maju mundurnya atau bahkan untuk-tegaknya negara.sebagai rujukan kehidupan bermasyarakat,berbangsa dan bernegara,konstitusi perlu hadir dan hidup dalam tingkah laku keseharian segenap warga negara (the living constitusion).dengan kata lain,tanpa bermaksud mengabaikan faktor struktur hukum dan subtansi hukum,sasaran yang dimaksud yakni 
bagaimna merokontruksi budaya hukum masyarakat sebagai pilihan mencegah dan meberantas korupsi.hal itu berarti bagaimana menjadikan konstitusi sebagai praktik nyata kehidupan dalam rangka mencegah dam memberantas korupsi.

Apabila suatu negara tidak menjadikan konstitusi sebagai sumber hukum berarti negara terssebut tidak memiliki landasan dan tidak memiliki aturan.tentunya apabila tidak ada aturan landasan maka sebuah negara akan berantakan karena seluruh masyarakat tertu berbuat sesuai keegoisan masing-masing.jika konstitusi tidak ditegakkan dalam suatu negara maka pondasi negara akan rapuh karena konstitusi merupakan hukum dasar negara.

Secara lebih sederhana,dalam proses pembiasaan dan penciptaan,pembudayaan konstitusi dalam mendongkel kejahatan korupsi dapat dilakukan melalui laku hidup keseharian dan dalam lingkup ruang terkecil,yakni keluarga dan lingkungan tempat tinggal sekitar,perlu dibentuk ruang-ruang diskursus sederahana agar tercipta proses fasilitas kesadaran berkonstitusi.sebelumnya kita tahu bahwa dalam hal itu konstitusi ialah UU,nah UU itu hukum dasar negara indonesia.ketika adanya sebuah kasus korupsi dia sangat berperan penting ketika konstitusi itu untuk mengatasi kasus itu yang dimana sebagai sumber dan landasan hukum yang terjadi tindak pidana korupsi.Konstitusi menjadi pedoman/acuan dalam penyelengaraan negara yang tidak hanya mengikat pemerintah/aparatur pemerintah tetapi juga warna negara.

\section{ORGAN DAN FUNGSI KEKUASAAN NEGARA}

Demokrasi Indonesia periode parlementer (1949-1959) Periode kedua pemerintahan negara Indonesia merdeka berlangsung dalam rentang waktu antara 1949-1959.Pada periode ini terjadi dua kali pergantian undang-undang dasar, yaitu:Pergantian UUD 1945 dengan Konstitusi RIS pada rentang waktu 27 Desember 1949 - 17 Agustus 1950.Dalam rentang waktu ini, bentuk negara Indonesia berubah dari kesatuan menjadi serikat. Sistem pemerintahan berubah dari presidensil menjadi quasi parlementer.Pergantian Konstitusi RIS dengan Undang-undang Dasar Sementara (UUDS) 1950 pada rentang waktu 17 Agustus 1950 - 5 Juli 1959.Periode pemerintahan ini bentuk negara kembali berubah menjadi negara kesatuan. Sistem pemerintahan menganut sistem parlementer.Dengan demikian, dapat disimpulkan bahwa pada periode 1949-1959, negara Indonesia menganut demokrasi parlementer.

Periode kedua pemerintahan negara Indonesia merdeka berlangsung dalam rentang waktu antara 1949-1959.

Pada periode ini terjadi dua kali pergantian undang-undang dasar, yaitu:

Demokrasi Indonesia Periode Parlementer (1949-1959)

Pemerintahan masa revolusi kemerdekaan Indonesia (1945-1949)

Pemerintahan parlementer (1949-1959)

Pemerintahan demokrasi terpimpin (1959-1965)

Pemerintahan orde baru (1965-1998)

Pemerintahan orde reformasi (1998-sekarang)

Demokrasi Indonesia periode parlementer (1949-1959) 
Periode kedua pemerintahan negara Indonesia merdeka berlangsung dalam rentang waktu antara 1949-1959.

Pada periode ini terjadi dua kali pergantian undang-undang dasar, yaitu:

1.Pergantian UUD 1945 dengan Konstitusi RIS pada rentang waktu 27 Desember 1949 - 17 Agustus 1950.Dalam rentang waktu ini, bentuk negara Indonesia berubah dari kesatuan menjadi serikat. Sistem pemerintahan berubah dari presidensil menjadi quasi parlementer.

2.Pergantian Konstitusi RIS dengan Undang-undang Dasar Sementara (UUDS) 1950 pada rentang waktu 17 Agustus 1950 - 5 Juli 1959.Periode pemerintahan ini bentuk negara kembali berubah menjadi negara kesatuan. Sistem pemerintahan menganut sistem

parlementer.Dengan demikian, dapat disimpulkan bahwa pada periode 1949-1959, negara Indonesia menganut demokrasi parlementer.Sistem pemerintahan yang dianut oleh Negara Republik Indonesia adalah sistem pemerintahan presidensial.Dalam sistem presidensial, kedudukan presiden cukup kuat. Hal ini karena presiden merupakan kepala negara sekaligus kepala pemerintahan.Tugas dan kewenangan presiden yang sangat banyak tidak mungkin dikerjakan sendiri. Sehingga memerlukan orang lain untuk membantunya.Dalam melaksanakan tugasnya, Presiden Republik Indonesia dibantu wakil presiden, serta beberapa kementerian negara yang dipimpin oleh menteri-menteri negara.Keberadaan Kementerian Negara Republik Indonesia diatur secara tegas dalam Pasal 17 UUD 1945 yang menyatakan:Presiden dibantu oleh menteri-menteri negara.Menteri-menteri itu diangkat dan diberhentikan oleh presiden.Setiap menteri membidangi urusan tertentu dalam pemerintahan.Pembentukan, pengubahan, dan pembubaran kementerian negara diatur dalam undang-undang.Selain diatur UUD 1945, keberadaan kementerian negara juga diatur dalam sebuah undang-undang organik, yaitu Peraturan Presiden Republik Indonesia Nomor 7 Tahun 2015 tentang Organisasi Kementerian Negara.

Undang-undang tersebut mengatur semua hal tentang kementerian negara, seperti:

-Kedudukan

-Tugas pokok

•Fungsi

-Susunan organisasi

-Pembentukan

-Pengubahan

-Penggabungan

-Pemisahan atau penggantian

-Pembubaran atau penghapusan kementrian

-Hubungan fungsional kementerian dengan •lembaga pemerintah non-kementerian dan pemerintah daerah

•Pengangakatan dan pemberhentian menteri

dalam perjalanannya DPD dalam sistem ketatanegaraan Republik Indonesia yang anggotaanggotanya dipilih langsung melalui pemilu ternyata di dalam konstitusi hanya diberi fungsi yang 
sangat sumir dan nyaris tidak berarti dibandingkan dengan biaya politik dan proses perekrutanya yang demokratis,DPD hanya diatur dalam dua pasal (pasal $22 \mathrm{C}$ dan Pasal $22 \mathrm{D}$ ). Adapun Upaya Penguatan Kapasitas Kelembagaan DPD RI Untuk itu DPD telah berupaya mengusulkan perubahan UUD khususnya pasal 22 D. Ini artinya diperlukan mengamandemen lagi UUD 1945. Hal ini dimungkinkan sebagaimana ketentuan pasal 37 ayat 1 UUD 1945. Usul itu tersebut dilandasi pertimbangan: Bahwa DPD RI memiliki legitimasi yang kuat karena dipilih secara langsung oleh rakyat, karena itu seharusnya memiliki kewenangan formal yang tinggi.

Jika dlm suatu pemerintah terdapat Perdana Menteri, maka dapat dipastikan bahw sistem pemerintahan yang digunakan adalah sistem parlementer. Karene beradaan perdana menteri menjadi salah ciri utama sistem pemerintahan parlementer.

Keberadaan DPD memang sampai saat ini masih menimbulkan diskursus karena selain kewenangannya yang terbatas, kedudukannya juga masih abu-abu apakah sebagai senator (senator bisanya digunakan di negara-negara federal sementara di Indonesia menganut negara kesatuan) atau justru hanya co-legislator, dan secara kelembagaan apakah sebagai lembaga utama dalam rumpun legislatif atau justru hanya sebagai penunjang. Sehingga keberadaan DPD masih perlu dikaji untuk ditempatkan pada posisi yang tepat dalam sistem ketatanegaraan dengan tugas dan fungsi yang tepat pula.

Dalam sistem pemerintahan presidensil, presiden tidak bertanggungjawab kepada parlemen karena kedudukan presiden sejajar dengan parlemen (DPR), posisi masing-masing saling mengimbangi antara satu dengan lainnya.

Larangan rangkap jabatan dimaksudkan agar fungsi-fungsi setiap cabang kekuasaan dapat berjalan efektif. Jika terjadi rangkap jabatan, maka siapa yang akan mengawasi dan siapa yang akan diawasi. Misalnya seseorang yang menduduki jabatan sebagai anggota DPR dengan fungsi pengawasannya dan disisi lain juga menjabat sebagai menteri, dlm kondisi demikian fungsi pengawasan DPR tdk akan efektif.

Sebenarnya pejabat pejabat dilingkup yudikatif juga dipilih oleh rakyat, tetapi mekanismenya bukan pemilihan langsung seperti untuk memilih anggota DPR dan Presiden.

Lembaga-lembaga negara yang terbagai kedalam tiga rumpun kekuasaan (legislatif, eksekutif, dan yudikatif) ataupun lembaga negara diluar dari ketiga rumpun kekuasaan tersebut kedudukannya sedejarat dan tidak ada yg subordinat khususnya setelah amandemen UUD. MPR, DPR, Presiden, MK dan MA kedudukannya sederajat, tidak ada yang lebih tinggi dan yang satu tidak bertanggungjawab kepada yg lainnya.

Presiden sebagai kepala pemerintahan bertanggungjawab terhadap pelaksanaan tugas dalam bidang eksekutif. Sedangkan dalam posisi sebagai kepala negara seorang Presiden melaksanakan segala kewenangan termasuk urusan luar negeri 